The disposition, exhibited by a portion of the pubiic press, to place everything connected with lunacy practitioners in a false light has attained to such a pitch, that medical men now refuse, not only to sign certificates of insanity, but to incur any amount of responsibility in relation to the confinement of the insane. It is time that the medical press should resolutely grapple with this important matter, and rush to the rescue of a much-maligned and persecuted, but nevertheless, I hope, respectable and honourable, section of the medical republic. I am, Sir, your obedient servant,

December 19th, 1859

\section{REGISTRATION OF DEATHS IN SCOTLAND.} To the Editor of THE LANCET.

SiR, - The remarks in your leading article of the 3rd inst. regarding the payment of fees for certiticates of the causes of death will, I fear, promote an agitation which must be ineffectual, and so tend to injure the profession in the eyes of the public. It is true, as you say, that " the labourer is worthy of his hire ;" but we must remember that in making a bargain, both parties must be agreed as to the valne of the article. Now, $I$ fear that neither the Government, the Parliament, nor the public of this country have the least idea of the value of the statistics of disease. When the Registration Acts were first introduced, the recording of the causes of death formed no part of the measure, but was engrafted on it at the earnest in stigation of the medical profession; and there is now a call upon us to show that in urging this we were actuated by zeal for science, not by a desire for gain. If the paltry fee of one shilling were paid for each certificate of death in the United Kingdom, trifling as the sum to each practitioner would be, it would cost the country npwards of $£ 25,000$. How many in Parliament would be found to consider medical statistics worth that sum? But such a fee would be degrading to the profession: if, then, we make it five shillings, the cost would be 2125,000 ; and $I$ believe that few even amongst medical men would venture to ask for such a grant.

The question for dispute must therefore be, whether we will continue to grant certificates without remuneration, or deprive ourselves of the only means of obtaining statistics of disease If we are determined to "strike," the public will probably let us have our own way, and the causes of death will be onitted from the registers. Will this result be satisfactory to the profession? I believe not. I would humbly suggest that we should quietly go on with the present system a little longer, in the hope that the collection of the statistics of disease may lead to some important public benefit, which will convince the country that such statistics are worth paying for.

I think, however, that we may reasonably ask that whilst we continue to supply the information of the causes of death, some use may be made of it. The new system of registration in Scotland has been in operation five years; but no tables of the causes of death in country districts, or in all Scotland, have been published. There have been monthly reports of the causes of death in the eight principal towns; but the certificates furnished for that number of years, at such an amount of trouble and annoyance, by country practitioners, are still lying uselessly in the hands of the parish registrars. Some time ago, I addressed the secretary to the Registrar-General for Scotland on this subject, and was informed that "the Registrar-General is fully alive to the importance and value of such information, and materials are being collected for the preparation of tables applicable to the whole of Scotland." But such tables, by being so long delayed, have lost nearly all their value. There would not be much greater difficulty in appending to the quarterly reports, now published, tables showing the canses of death, during the quarter, in each of the counties, than in preparing similar tables for the eight towns once a month, as is now done; and such tables would be highly instructive.

I am, Sir, your obedient servant

Dollar, N.B., Dec. 12th, 1859.

JoHn M. STRachan, M.D.

\section{PASTEBOARD VERSUS PAPIER MACHÉ. To the Editor of THE LANCET.}

Sire,-If Mr. Acton will kindly refer to The LANCET of Dec. 3rd, he will find he made use of the words-."They (the splints) are exceedingly light, firm, and inexpensive, being manufactured in pasteboar "d or papier mache."

I still consider, to use Mr. Acton's words, that he has found a "mare's nest" in the new splints he exhibited to the Medical and Chirurgical Society, as he has failed to point out that the papier maché system possesses any superiority over the pasteboard, except the elegance, and that is more than counterbalanced by the ready method, if I may so term it, of applying the pasteboard splints.

I do not consider it presumptuous on my part to make these remarks, as I have seen hundreds of fractures treated with the pasteboard, which is quite as capable of being moulded to the limb (if properly done) as papier maché.

I am, Sir, yours obediently,

E. C. Garland, M.R.C.S. Silver-street, Teovil, Dec. 1859. Late Senior House-Surgeon,

\section{HAY ASTHMA.}

To the Editor of The LANCET.

SrR, - Several English authors-Bostock, Gordon, Elliotson, Prater, King, Mackenzie, and others - have described, under the denominations of summer catarrh, summer bronchitis, hay fever, hay asthma-a catarrh which, in some persons predisposed to it, returns annucelly, and, for the most part, during the whole of life, at the end of May or the beginning of June, lasting some weeks or even two months. The symptoms are mostly coryza, with frequent sneezing, inflammation of the conjunctiva and of the throat, cough, asthma, slight fever, or similar symptoms.

Occupied with studies on this disease, which occurs also in Germany, France, \&c., I should feel greatly obliged if English, Scotch, or Irish physicians would be so kind as to give me answers to the following questions:-

1. Does this disease occur also in Scotiand or Ireland? Does it affect natives of these countries, or merely strangers?'

2. Does it occur more frequently in towns or in the conntry?

3. Does it occur more often in those countries where a greater amount of rye or other corn is cultivated, or where there are more meadows?

4. Is it true that it appears almost exclusively amongst the higher ranks of society, or has it only been overlooked amongst the poorer classes?

Any other information tending to increase our knowledge of the disease, or the narration of cases, would extremely oblige me. Even the mere communication of the number of cases which a colleague has observed, with indication of the sex of the patients, and at what age the disease had first appeared, would aid me for a statistical survey.

I offer my sincere thanks beforehand for this trouble, and am ever ready to afiord reciprocal services. I will also name gratefully in the preface of a treatise, which I shall publish on tinis affection within about two months, those physicians who will be kind enough to assist me by communications. I, therefore, beg that the honoured colleagues may write their proper names and dwelling-places very legibly.

Letters may be addressed, 4, St. Martin's-place, Charing. cross, London, care of Dr. James Hunt.

I am, Sir, your obedient servant,

Giessen (Grand Dukedom of Hessia), $\quad$ DR. P. PHaebus December, 1859. Professor of Medicine at the Med. Faculty.

\section{ADULTERATION OF FLOUR.}

To the Editor of THE LANCET.

SIR,-Are you aware that Indian corn-meal, and secondquality flour, are extensively adulterated with an article inported from Ireland, called shouds?

In the manufacture of oatmeal there is a refuse product known as "shelling-seeds," which is the husk of the grain, and which was formerly thrown ont of the mill as valueless, forming quite a hillock. These heaps have lately disappeared, and shelling-seeds are now oround into shouds, ostensibly for pig feeding, but in reality for the adulteration of human food, chiefly in the populous manufacturing districts of England; and no small quantity of it is reimported into Ireland for a like nefarious purpose, in districts where oatmeal mills do not exist, at which the article may be got at first hand.

Shouds resembles second-class flour; it is ground fine, and is of a light-brown colour. There is no nutriment in it; but what is worse is, that its sharp spicular particles irritate the mucous membrane, producing diarrhoa, dysentery, and sometimes death itself.

A few months ago, a mill in this county was burnt to the ground; six or seven persons lost their lives, and as many 655 